\title{
12 Social media as a sphere of political disruption
}

\author{
Trust Matsilele and Bruce Mutsvairo
}

Since the turn of the millennium, there has been a proliferation of social media use in political and ideological contestations. This proliferation has been reflected in a raft of scholarship that seeks to cognise the potential of new communicative technologies. A cursory look at the studies conducted demonstrates that most research has tended to look at the nexus of social media and elections, democratisation, political activism and protests (Mäkinen \& Wangu Kuira, 2008; Wasserman, 2011; Mpofu, 2013; Smyth \& Best, 2013; Mare, 2014, 2016; Mhiripiri \& Mutsvairo, 2014; Chitanana \& Mutsvairo, 2019; Matsilele \& Ruhanya, 2020; Mpofu \& Matsilele, 2020; Mutsvairo \& Ronning, 2020). What remains under-studied, with an exception of the few studies in the Western hemisphere, is the relationship between social media and political disruption in political hybrid systems where there are cosmetic freedoms and elements of dictatorship co-existing side by side like in the case of Zimbabwe. Just like normal democracies, Zimbabwe holds elections every five years, but the same elections are marred by violence, legitimacy deficit and dual deployment of law and other coercive apparatus of the state. Writing on hybrid political systems, Levitsky and Way (2010:1) intimated that:

Unlike the single-party or military autocracies that predominated during the Cold War era, regimes in Kenya, ... Zambia, Zimbabwe, and elsewhere were competitive, in that opposition forces used democratic institutions to contest vigorously — and at times successfully - for power. Nevertheless, these regimes were not democratic with government critics suffering harassment, arrest, and in some cases, violent attacks, and electoral fraud, unfair media access, and abuse of state resources skewed the playing field heavily in favour of incumbents. In other words, competition was real, but unfair.

It is in these hybrid systems where social media has been used to supplement offline activities that often have attracted severe punishment from the state as evidenced by use of naked violence in Zimbabwe in August of 2018 and January of 2019 when live ammunition was used on unarmed civilians.

DOI: $10.4324 / 9781003111962-12$ 
Of importance, however, is the effective use of social media as a platform for potential alternative discourses and narratives, which leaves these digital arenas attractive in authoritarian states as subalterns, which Spivak (1988) equates to the oppressed victims of cultural imperialism can dress parodies on social media and employ them as "foot soldiers" to fight against oftentimes oppressive and despotic regimes. It is social media's enabling capacity to use parody accounts, where citizens are not compelled to use their real identities but they can use avatars, made up identities, multiple identities, or stay anonymous that has ignited its popularity (Coleman, 2014). The use of parody accounts was in use as recent as 2020 in Nigeria with the \#EndSars protests that sought to push back against the state sponsored brutality (Bodunrin \& Matsilele, forthcoming). In countries such as Kenya, Democratic Republic of Congo (DRC), Nigeria, Togo and Zimbabwe were electoral outcomes have been contentious, digital media has become an alternative space for contestations and counter-narratives. It is this contestation that leads Banda (2010: 8) to intimate that, 'citizens through social media are beginning to own their own media and counter the effects of years of reportorial neglect occasioned by an unhealthy concentration of media ownership' and enjoy monopoly traditionally reserved for elites only (Mutsvairo and Sirks, 2015). Notwithstanding these promises of social media, there are still challenges around access, affordability and connectivity which explain, in part, why most Africans remain disconnected from the so-called information superhighway. Despite these challenges, social media could be used to broaden political participation by helping citizens to communicate with their representatives and with each other (Valenzuela et al., 2009). It is this aspect by Valenzuela et al. (2009) that informs this study - in a bid to understand how social media is employed to disrupt the communicative aspect of power. In Zimbabwe, actors who disrupt power have often been dressed in terms that attract annihilation, terms such as dissidents. This characterisation of opponents as dissidents in Zimbabwe has a history. "Dissidence" is vapanduki or what the current President Emmerson Mnangagwa calls mhanduin reference to enemies and rebels of the state (Matsilele, 2019). This specific form of dissidence that occurs mostly on social media platforms is what this chapter refers to as social media dissidence. In this chapter, we ask if it has some decolonialising effect.

\section{Theoretical framework}

The study employed two theoretical lenses: a reconfigured public sphere and subalternity. The public sphere of social media is not even strictly "public" because social media platforms are privately owned, and the public can be locked out or banned from the app by the corporate owners or by other users. Furthermore, assumptions that social media are available for free to the public remain largely illusory because the companies that own such 
platforms are constantly collecting users' data to sell or to use it to learn more about the users' habits (Isaak \& Hanna, 2018). The owners also make money from users through constant software upgrades. Thus, when the framing concept of public sphere is in relation to social media use, the intention is to modify the terms "public" and "sphere" so that they fit the following: the Zimbabwean context, the political concept of "public", the sociological concept of "social" and the communication concept of "media". This bundle of ideas makes up a kind of public sphere that Habermas would probably struggle to recognise straight away. This is because there is a concept that is unique to Zimbabwe that explains the public sphere a bit more organically than Habermas' coffee shop model. For its part, Zimbabwe offers the concept of dariro or playground. The second theoretical lens used in this study considers dissidence to be a subaltern practice, a claim that simultaneously opens opportunities and limitations for the current chapter. Mpofu (2015: 83) has argued that 'the Web 2.0 has revolutionised participation in salient public discourses of those ostracised Zimbabwean members of society' whom Fanon (1969) and Gramsci (1971) have categorised as "the wretched of the earth" or "subaltern" respectively. Like in the case of the public sphere, the study is not limited to seeing the subaltern in relation to post-colonial India or Mussolini's Fascist Italy. The subaltern of Zimbabwe is a product of Zimbabwe's history, whose identity and agency are now refracted through the keypad, touch screen and camera of a smartphone. When one reads subaltern theory into Zimbabwe, what comes out is something else that looks and sounds like Spivak's subaltern dictum (1988), but with a Zimbabwean kongonya (a provocative dance) flavour. That fundamental shift should be considered. This shift welds the subaltern margins to the public sphere, mediated by hashtags, memes, trolls, news feeds, timelines and so on.

\section{Research methodology}

To understand the phenomenon of social media dissidence in Zimbabwe in as far as political disruption is concerned, the study employed qualitative methodology with research designs of virtual ethnography and case study. Online ethnography refers to a number of related online research methods that adapt to the study of the communities and cultures created through computer-mediated social interaction (Bowler, 2010: 1270). In this case, the researchers studied the emerging culture of political disruption mediated in Zimbabwe's virtual public sphere. The second design used was the case study. Case studies, in their true essence, explore and investigate contemporary real-life phenomenon through detailed contextual analysis of a limited number of events or conditions, and their relationships (Tellis, 1997; Zainal, 2007). This chapter focused on \#ThisFlag movement to understand how "dissidents" are disrupting hegemonic narratives in Zimbabwe's reconfigured public sphere. 


\section{Discussion and analysis}

\section{The political disruption of \#ThisFlag movement}

\#ThisFlag begun in April 2016 led by Evan Mawarire, then a 41-year-old Zimbabwean pastor who appeared with a Zimbabwean flag draped around his neck and shoulders in a video posted on Facebook, YouTube and Twitter. \#ThisFlag uses social media to register widespread socio-economic anger against the Zimbabwean state. The movement also uses social media (Twitter and Facebook) to mobilise support against what it considers a repressive state a view Gainous and Wagner (2014: 136) theorise when they say, 'social media allows political actors to garner support beyond the purview of mainstream media'. Mawarire also uses the social media platform due to its affordability and uniqueness in terms of communicating with his target audience. \#ThisFlag would never have taken off in 1990, 2000 or 2010 when ZANU-PF monopolised the airwaves. As Gainous and Wagner (2014: 136) have further observed, 'the result is that campaigns on the Internet are an alternative that allows competition where limited resources might have provided none' and for the case under study competition beyond the political direction of the country extends to control of narratives in the country's virtual public sphere.

The social media campaign allows for easier outreach and education of the voters at a fraction of the cost of traditional media. While Mawarire is not always directly targeting voters, his targets - citizens - particularly those opposed to the ruling party - potentially wield the same power as voters who could punish elected officials at the ballot box. The movement is active on Facebook and Twitter. On the Twitter platform, the campaign operates under several handles, such as \#ThisFlag and E Mawarire @ PastorEvanLive. On Facebook, the movement uses the names Mawarire and This Flag/Ifulegi Leyi/Mureza Uyu. As of April, 2021, on Facebook, Mawarire's handle had 94,169 followers, while This Flag/Ifulegi Leyi/Mureza Uyu had over 120000 likes and followers combined. On Twitter, Mawarire had over 325,000 followers early 2021 .

\section{History of the movement}

The movement uploads self-made videos of Zimbabweans venting against the state, and sometimes trolling it. The rallying call is around the significance of the national flag which they say originally represents noble values such as shared prosperity, democracy and the country's potential in agriculture and mining, but which has now been soiled and inverted, they argue, by ZANU-PF. The posts are made by users mostly using their real identities. For instance, Mawarire, unlike Baba Jukwa (another social media dissident who used an alias), has a traceable biography, a factor which points to his distinct mode of dissidence. He grew up in Mazowe, about 37 
km outside Harare, where he attended Prince Edward High School and the Harare Institute of Technology. He is a married family man with two children. Mawarire is the charismatic leader of His Generation Church, a small church in Zimbabwe's capital Harare. \#ThisFlag began with a four-minute video, posted on 20 April 2016 on Facebook, WhatsApp, YouTube and Twitter (Musarurwa, 2016).

The video went viral, gaining 77,000 views on YouTube and 185,000 on Facebook. He also tweeted, on the same day he posted the video, "So I had a little rant \& it has turned out to be how so many Zimbabweans feel". By May 2018, Mawarire had posted over 3,400 tweets and over 430 photos and videos. There were also thousands of comments, over 7,000 likes and retweets. By 5 May 2018, Mawarire had 204,000 followers. On the 5th of July 2016, Mawarire posted a video exhorting Zimbabweans to stay away from work the next day as part of a nation-wide shutdown. Over 48,000 followers viewed the video. The video was coupled with a poster calling on Zimbabweans to stay at home and not report for work. The poster was loved 103 times, retweeted 126 times, with 14 replies.

The shutdown was successful, leading to the government charging Mawarire with treason, an offence punishable by death in Zimbabwe. After a court appearance and securing bail, Mawarire skipped the country at the end of July 2016, first to South Africa, then to the United States, where he currently lives. While in South Africa, he continued to drum up support across South African churches and universities.

After skipping the country, Mawarire would become a guest of local, regional and international media outlets. Among them were CNBC Africa, CNN, BBC, SAFM, Kaya FM, 702 and EWN. His family followed him to exile to South Africa and then the U.S. It is these transitions between online first then offline that is also of interest to understand as dissident figures like Mawarire start by employing tools at their disposal and then transition to bigger platforms once they have built a critical following online. After a stay outside Zimbabwe of seven months, Mawarire returned to Zimbabwe on 1st of February 2017, where he was immediately arrested on entry. He has since relocated to the United States.

\section{Findings and analysis}

\section{Discussion of types of content: \#ThisFlag}

Four types verbatim emerge on Mawarire's \#ThisFlag's page: call to action, protest, motivational and trolling. The content on Mawarire's Twitter and Facebook handle, like Baba Jukwa's, has as its end the throwing of power into disarray by asking uncomfortable questions, employing tactics that are difficult to censor or prohibit (that is, actions that can only be censored at great reputational cost to the regime), and encouraging followers to bypass traditional gatekeepers by self-recording and uploading content 
that makes the government look incompetent or just plain bad. The content on Mawarire's \#ThisFlag page is also meant to inspire "courage" against alleged tyranny without engaging in an open combat. Unlike other digital dissidents like Baba Jukwa and Tajamuka who call for physical confrontation with the state, Mawarire opts for what could be considered more of a "Martin Luther King approach" - confronting power through peaceful means and powerful oratory rhetoric which mobilises citizens to courageously confront, question and expose the hypocrisy demonstrated by powerful elites.

Table 12.1 demonstrates some of the identified broader categories of Mawarire's disruption.

Mawarire posted different kinds of content. His very first, famous video is an example of protest. This is because it questions the leadership of the country, asking for a balance sheet of what it has done since taking over after independence. He laments the state of the economy and argues that the country is a far cry from what it should be. In this way, Mawarire fires the imaginations of Zimbabwe, partly by invoking nostalgia for a functional Zimbabwe (late 1980s to mid-1990s). Mawarire also posted many other videos besides the first well-known video. For instance, he posted the video calling for the national shutdown. We categorised that video as "call to action". This is because he is urging fellow citizens to stay away as a sign to the government that citizens will not sit by and watch while governing party runs down the country through corruption and incompetence. Staying away from work is one example of peaceful protest which is difficult to

Table 12.1 Broader categories of Mawarire's disruption

\begin{tabular}{|c|c|c|c|}
\hline Type of content & Example 1 & Example 2 & Example 3 \\
\hline Protest & $\begin{array}{l}\text { Mboko (then vice } \\
\text { president) buda } \\
\text { muhotera ( } 24 \\
\text { June 2016) }\end{array}$ & $\begin{array}{l}\text { We don't want them } \\
\text { (Bond Notes) } \\
\text { debate with RBZ } \\
\text { governor (10 June } \\
\text { 2016) }\end{array}$ & $\begin{array}{l}\text { Another rant } \\
\text { against Mugabe. } \\
\text { There will be } \\
\text { more no doubt } \\
\text { (1 June 2016) }\end{array}$ \\
\hline Call to action & $\begin{array}{l}\text { Let's gather to } \\
\text { honour Dzamara }\end{array}$ & $\begin{array}{l}\text { Shut down } \\
\text { Zimbabwe (5 July } \\
\text { 2016) }\end{array}$ & $\begin{array}{l}\text { Undenge Must go } \\
\text { (2 July 2016) }\end{array}$ \\
\hline Trolling & $\begin{array}{l}\text { Notice to sue police } \\
\text { over malicious } \\
\text { arrests (23 March } \\
\text { 2018) }\end{array}$ & $\begin{array}{l}\text { Celebrating } \\
\text { blockage of } \\
\text { Beitbridge border } \\
\text { (1 July 2016) }\end{array}$ & $\begin{array}{l}\text { Profiling NERA } \\
\text { demonstration } \\
\text { (26 August 2016) }\end{array}$ \\
\hline $\begin{array}{l}\text { Informational/ } \\
\text { motivational }\end{array}$ & $\begin{array}{l}\text { Updates on } \\
\text { his speaking } \\
\text { engagement } \\
\text { at Geneva ( } 20 \\
\text { February 2018) }\end{array}$ & $\begin{array}{l}\text { Updating followers } \\
\text { about meeting } \\
\text { Mapfumo (20 } \\
\text { August 2016) }\end{array}$ & $\begin{array}{l}\text { Inviting } \\
\text { Zimbabweans } \\
\text { to attend court } \\
\text { in support for } \\
\text { Tajamuka activist } \\
\text { (26 August 2016) }\end{array}$ \\
\hline
\end{tabular}


censor. It had previously been used successfully by the nation's trade union federation ZCTU and the MDC in the late 1990s and early 2000s but had fallen into disuse as the citizenry became apathetic from the mid-2000s onwards (Zeilig, 2016; LeBas, 2006). In the same month as the \#Shutdown Mawarire would post another video with a different kind of tone and message, saying:

Fellow citizens let me thank you for standing up to this government over corruption and injustice......Today I want to thank political and civil activists who have stood up against this government for a long time. It is because of you that we are also standing up now... Nothing is called useless when it comes to challenging this government as far as running our country is concerned...... Hatichada uye hatichatya (we are no longer afraid and can't take this anymore).

Here, Mawarire is not merely expressing his thanks and praises to dissidents_ past and present_but he acknowledges a debt and genealogy of dissidence in Zimbabwe. This aspect strengthens this study's contention that dissidence in Zimbabwe is deeply rooted in history, not just a social media phenomenon. At the same time, by saying "Hatichada uye hatichatya" translated to mean "we are tired and we are no longer afraid," he seeks to embolden the masses with a rare ray of hope in a country, where amid government denials, opposition officials believe has become a possible outpost of tyranny. Is it a mere bluff to say he and his followers are "no longer afraid". The evidence suggests that indeed some Zimbabweans - once they resolve to fight - do so with their lives. Spirit medium Nehanda facing death declared "Mapfupa angu achamuka" or "My bones will rise again" while the Second Chimurenga guerrillas sang "Amai naBaba/musandichema kana ndafa/nehondo" (Mum and dad, do not weep for me if idea in this struggle). These words are words of resolve and when Mawarire says "hatichatya" he could be evoking historical precedence of paying the ultimate price in pursuing freedom and justice.

Another type of content that Mawarire posts is what we categorise as informational. Dissidents should demonstrate to followers that their actions are working, to inspire citizens to continue to be engaged. Mawarire does this by giving periodic updates to the followers of his speaking engagements in Geneva, at the United Nations, and meetings with eminent persons such as civil rights movement leaders in the USA and anti-apartheid activists in South Africa. Such connections help show to Mawarire's constituency that their fight has support across the world. The oxygen of visibility is important to social media dissidence. Below Mawarire was captured with one of South Africa's late struggle icons, Ahmed Kathrada, who spent over two decades in Robben Island with Nelson Mandela.

Mawarire is not the only contributor to videos and messages to \#ThisFlag. Indeed, \#ThisFlag rose to become a movement precisely because it 
quickly outgrew Mawarire himself. For instance, we see two anonymous youths from Kadoma who "joined" the movement in April of 2016 and immediately posted a video of themselves holding the Zimbabwean flag and addressing themselves to the country's President:

Dear Patriarch Mugabe, our roads from Kadoma to Jarahwa are dilapidated. The Chinese who are doing mining here are not assisting the situation. The seeds you are sending isn't getting to the intended beneficiaries. We are asking that you question the member of parliament from our region regarding to any development he has brought to the area since he got elected.

We seek to categorise this content as "protest". This is because it seeks to expose members of parliament, who get trapped through the benefits of positions they occupy and thereby forget the historical mandate of serving the people. This is the historical Fanonian pitfalls of national consciousness. The critique it levels at "Dear Patriarch Mugabe" is of a kind that we consider condescending mockery (kusvereredza). It appears that the youths were attaching a title to Mugabe they knew he did not deserve. Another Zimbabwean, Harris Madhuku, was influenced by \#ThisFlag to "protest" and thereby posted a video in English, saying that:

Today I want to talk about how things are being run in the country. There is something troubling especially the quick implementation of instant laws at the port of entry in Beitbridge it's a sign of dryness and barrenness in terms of ideas. They are running our country like they are running their houses or a tuck shop.... Other countries see us as stupid people.... The Occupy Africa Unity Square activists were charged with attempted robbery, how can you ask for a one "thousand-dollar bail in a country where you can't withdraw two hundred dollars... We kind have a country being run by greedy minds, come out of comfort zones when you see people protesting join that demonstration. They can't sleep in mansions whilst we sleep in streets....

The researchers considered this content as call to action. This is because it urges citizens to be active and join protests the way the country is run. Interestingly, the call to action is not made by Mawarire, but by fellow Zimbabweans responding to \#ThisFlag's original call to action to make their own calls to action. Thus, \#ThisFlag becomes a rallying point. This is a kind of piggybacking on dissidence - where dissidence spawns more dissidence. Opposition leader Madhuku, whose message is that Zimbabwe has been privatised by an elite and that citizens should fight back to retake the country, has been mobilised to mobilise others. \#ThisFlag had grown beyond Mawarire and even beyond the hashtag. Even though Mawarire was confined to the online space, his "followers" push for other varieties of engagement that 
spill out into the streets. In May 2016 two war veterans, also from Kadoma, posted a video in which they said:

I also hold my flag to Mr President to register my disgruntlement. There was a company that was here, it has now closed down; this company was owned by your fellow liberation fighters. About 70 people were working here until the company got closed down. The people who were running this place were dispossessed of their belongings by ZIMRA and NSSA. These people who used to run this place are now desperate and we hope this message will get to you, so you can come and help the situation. Your fellow comrades are now surviving through selling marijuana). May you visit Kadoma, what is it about Harare that keeps you glued?

We categorise this content as trolling. This is because it exposes the failure of the country's leadership to take care of its citizens. This kind of trolling (kusvereredza) refers to how in-laws call out a husband who fails to take care of his wife (huramu). This is also closely related to what usually happens at "nhimbe", where husbands or fathers who fail to properly care of their families are exposed without the troll suffering any adverse consequences. We argue that these two war veterans are using social media to mediate the same role that "huramu" and "nhimbe" did. \#ThisFlag also caught on with Zimbabweans in the diaspora, some of them well-known back home. For instance, popular musician Thomas Mapfumo recorded his own video, a flag wrapped around his neck, berating the government for betraying the promises of the liberation struggle. Mapfumo said:

Hello Zimbabweans, my name is Thomas Tafirenyika Mapfumo Muchadura. I am a musician sympathetic to the cause of the poor. Let me tell you that freedom isn't color of the skin of those governing but respect of rights such as press, association and assembly. Let's leave corruption and theft, what is happening in our country is hard, thugs have invaded our country. Some who are pretending to be revolutionaries are not working for the people for themselves. Our president is a dictator he is the chief architect of stealing state resources and people are suffering. Evan Mawarire is a brave man and we hope God will help him as we fight going forward.

This study categorises Mapfumo's message as both trolling and protest. This is because it seeks to svereredza (troll) the government for its failure and labelling of Mugabe as a dictator and not a liberator. Mapfumo is a well-known dissident musician and in this message, he sees a lot of \#ThisFlag echoed in his music. This suggests that Mapfumo has always been doing \#ThisFlag, but in his own way. The power of \#ThisFlag, in this case, was not just to rally Zimbabweans to the colours but also to make different Zimbabweans see themselves in the movement and to evaluate their 
contributions to a "new struggle" that started in 1980. What Mapfumo is saying also dovetails with the message above by the two war veterans from Kadoma, accentuating the sense that the disillusionment in Zimbabwe cut across political party lines. Perhaps a new national awakening was afoot? A follower named Farana De Agostini recorded a video calling on Zimbabweans to "sustain the momentum". With Henry Olonga's "My Zimbabwe" in the background, De Agostini, who appeared to be fighting back tears, said:

We are finally standing as one, ThisFlag has given us hope. Hope for a better Zimbabwe, hope to look after our families......I am sure every Zimbabwean has a story to tell...we want to live like decent people again. We don't want any more pain and suffering. I cry today because the pain is great, but I am inspired because we are now one across our racial and class divide.

We categorised De Agostini's message as call to action. This is because it details personal experience that has national resonance across race, class and ideological divide. The message is also laden with subtle political undertones to build a Zimbabwe which is colourless and classless. The conclusion that "we are now one" seems to be a new imaginary rather than something real. In 1980 Robert had used the same reconciliation imaginary to say that "we are one" across race, colour and creed. \#ThisFlag, however, implies that Mugabe had abandoned this dream of patriotic "oneness". Henry Olonga's "My Zimbabwe" further contests the ownership of Zimbabwe. Who is a patriot? Who is Zimbabwean?

\section{Conclusion}

The study found that social media has given Zimbabwe's unique digital activists the power, in real or illusory sense, to challenge narratives often advanced by post-colonial hegemonies. The use of the social media platforms throws power into disarray, while also mobilising citizens to interrogate the power and authority of elites, potentially decolonising the remnants of imperialism disguised as freedom. The use of social media by cyber-terrorists or dissidents helped those in the margins to reclaim citizen voices and spaces that traditional media typically filters out. Using social media to challenge the authority of a state accused of using tactics employed by colonial powers demonstrates the decolinising effect of digital technologies. More research has to be carried out to determine to social media's potential as a political tool for decolonisation. One might say that social media platforms offer a space and a voice perhaps in the same way that coffee houses and restaurants did during Habermas' days - but there is more to it when it comes to social media. As this chapter might have shown, dissidentiality quickly spread beyond 
leading actors, spills over to their followers, into the streets, people's homes and workplaces, into their metaphors and verbal art, and so on. Trolls, sceptical followers, blind followers, conspiracy theories peddlers and leakers all were thrown into the mix, creating a powder keg of talk, discourse, emotions, insults, praises, debate, provocation, carnival and engaged citizenship. Everyone touched by this web becomes, by extension, a social media dissident.

\section{References}

Banda, F., 2010. Citizen journalism \& democracy in Africa. An exploratory study. Grahamstown: Highway Africa, pp. 1-93.

Bodunrin, T. and Matsilele, T. Forthcoming. 'I am Tyler Perry, I endorse the \#EndSARS protest': An examination the use of parody accounts in the fight for social justice in Nigeria. In Reading Justice Claims on Social Media, edited by T. Matsilele. Cham: Palgrave Macmillan.

Bowler, Jr., G.M., 2010. Netnography: A method specifically designed to study cultures and communities online. The Qualitative Report 15(5), pp. 1270-1275.

Chitanana, T. and Mutsvairo, B., 2019. The deferred 'democracy dividend' of citizen journalism and social media: Perils, promises and prospects from the Zimbabwean experience. Westminster Papers in Communication and Culture 14(1), pp. 66-80. DOI: http://doi.org/10.16997/wpcc.305

Coleman, G., 2014. Hacker, hoaxer, whistleblower, spy: The many faces of Anonymous. London, UK: Verso books.

Fanon, F., 1966. The wretched of the earth (1st Evergreen ed.). New York: Grove Weidenfeld.

Gainous, J. and Wagner, K.M., 2013. Tweeting to power: The social media revolution in American politics. Oxford: Oxford University Press.

Gramsci, A., 1971. Selections from the Prison Notebooks, edited and translated by Q. Hoare and G. Nowell Smith. London: Lawrence \& Wishart.

Isaak, J. and Hanna, M.J., 2018. User data privacy: Facebook, Cambridge Analytica, and privacy protection. Computer 51(8), pp. 56-59.

Levitsky, S. and Way, L.A., 2010. Competitive authoritarianism: Hybrid regimes after the Cold War. Cambridge: Cambridge University Press.

LeBas, A., 2006. Polarization as craft: Party formation and state violence in Zimbabwe. Comparative Politics, pp. 419-438.

Mäkinen, M. and Wangu Kuira, M., 2008. Social media and postelection crisis in Kenya. The International Journal of Press/Politics 13(3), pp. 328-335.

Mare, A., 2014. Social media: The new protest drums in Southern Africa. In Pătruţ, Bogdan, and Monica Pătruț, eds. Social media in politics: case studies on the political power of social media. Vol. 13. (pp. 315-335). Cham: Springer.

Mare, A., 2016. Baba Jukwa and the digital repertoires of connective action in a 'Competitive Authoritarian Regime': The Case of Zimbabwe. In Digital activism in the social media era (pp. 45-68).Cham: Palgrave Macmillan.

Matsilele, T., 2019. Social media dissidence in Zimbabwe (Doctoral dissertation, University of Johannesburg).

Matsilele, T. and Ruhanya, P., 2021. Social media dissidence and activist resistance in Zimbabwe. Media, Culture \& Society, 43(2), pp. 381-394. 
Mhiripiri, N.A. and Mutsvairo, B., 2014. Social media, new ICTs and the challenges facing the Zimbabwe democratic process. In Crisis Management: Concepts, Methodologies, Tools, and Applications (pp. 1281-1301). IGI Global.

Mpofu, S., 2013. Social media and the politics of ethnicity in Zimbabwe. Ecquid Novi: African Journalism Studies 34(1), pp. 115-122.

Mpofu, S., 2015. When the subaltern speaks: Citizen journalism and genocide 'victims' voices online. African Journalism Studies 36(4), pp. 82-101.

Mpofu, S. and Matsilele, T., 2020. Social media and the concept of dissidence in Zimbabwean politics. In The History and Political Transition of Zimbabwe (pp. 221-243). Cham: Palgrave Macmillan.

Musarurwa, H.J., 2016. The rise of youth activism and non-violent action in addressing Zimbabwe's crisis. Conflict Trends 2016(3), pp. 50-56.

Mutsvairo, B. and Ronning, H., 2020. The Janus face of social media and democracy? Reflections on Africa. Media, Culture \& Society 42(3), pp. 317-328.

Mutsvairo, B. and Sirks, L., 2015. Examining the contribution of social media in advancing political participation in Zimbabwe. Journal of African Media Studies 7(3), pp. 329-344.

Smyth, T.N. and Best, M.L., 2013, December. Tweet to trust: Social media and elections in West Africa. In Proceedings of the sixth international conference on information and communication technologies and development: Full Papers-Volume 1 (pp. 133-141). Cape Town, South Africa: ACM.

Spivak, G.C., 1988. "Can the subaltern speak?" In Colonial discourse and postcolonial theory, edited by P. Williams and L. Chrisman (pp. 66-111). New York: Columbia University Press.

Tellis, W.M., 1997. Application of a case study methodology. The Qualitative Report 3(3), pp. 1-19.

Valenzuela, S., Park, N. and Kee, K.F., 2009. Is there social capital in a social network site?: Facebook use and college students' life satisfaction, trust, and participation. Journal of Computer-Mediated Communication 14(4), pp. 875-901.

Wasserman, H., 2011. Mobile phones, popular media, and everyday African democracy: Transmissions and transgressions. Popular Communication 9(2), pp. 146-158.

Zainal, Z., 2007. Case study as a research method. Jurnal Kemanusiaan 5(1). pp. 1-6.

Zeilig, L., 2016. Struggle reawakens in Zimbabwe. Green Left Weekly, 1103 (July 24), p. 15. 